\title{
Cytotoxicity, Antiproliferative and Apoptotic Effect of $n$-Hexane Fraction of Lime Parasite (Dendrophtoe pentandra)
}

\author{
Subandrate', Masayu Farah Diba ${ }^{2 *}$, Salni ${ }^{3}$, Triwani ${ }^{4}$, Sri Nita ${ }^{4}$ \\ 'Department of Biochemistry, Faculty of Medicine, Universitas Sriwijaya, Palembang \\ ${ }^{2}$ Biomedical Program, Faculty of Medicine, Universitas Sriwijaya, Palembang \\ ${ }^{3}$ Department of Biology, Faculty Mathematics and Natural Sciences, Universitas Sriwijaya, Palembang \\ ${ }^{4}$ Department of Medical of Biology, Faculty of Medicine, Universitas Sriwijaya, Palembang \\ *Corresponding author email: farahdiba.unsri2011@gmail.com
}

Received: 16 Sep 2018; Accepted: 30 Jan 2019; Available online: 5 Jun 2019

\begin{abstract}
Breast cancer is one of the biggest causes of death in women in the world. Lime parasite (Dendrophtoe pentandra (L.) Miq.), a folk remedy used by Indonesian people, is believed to be efficacious as anticancer drug. This research aims to know the activity of $n$-hexane fractions of lime parasite in inhibiting the proliferation and apoptosis of T47D cells in vitro. Cytotoxic test with MTT method assay from $n$-hexane fractions used a multilevel concentration. Antiproliferative test was carried out by the method of MTT assay and cell doubling time was calculated at the time of duplication. Apoptotic test was done with concentration of $1 \quad I C_{50}$ and $1 / 2 I C_{50}$ which was analyzed by flow cytometry. The results reveals that fractions of lime parasite have cytotoxic activity with concentration of $\mathrm{IC}_{50}$ is included in moderate cytotoxic level. The result of the doubling time of the optimum fraction of $n$-hexane is in 31 hours with the concentration of $1 / 4 \mid C_{50}$. Results for the flow cytometry shows the fraction of $n$-hexane does not induce apoptosis in cells of T47D. Those results show that the active fraction of lime parasite has cytotoxic activity which is able to inhibit proliferation, but does not induce apoptosis of T47D cell.
\end{abstract}

Keywords: antiproliferative, apoptotic, cytotoxic, lime parasite, Dendrophtoe pentandra

\section{INTRODUCTION}

Breast cancer is a physical health problem causing morbidity and mortality (Torre, Bray, Siegel, Ferlay, Tieulent, and Jemal, 2015). Breast cancer is one of the biggest causes of death in women each year. In Indonesia, the prevalence of breast cancer in the year 2013 amounted to $0.5 \%$ with an estimated population of 61,682 cases (Depkes RI, 2015). WHO data in 2018 stated that cancer is the leading cause of death in the world with estimated 627,000 women died from breast cancer - that is approximately $15 \%$ of all cancer deaths among women. One of the countries that still utilizes traditional medicine by making use of medicinal plants is Indonesia. Some interviews, though not structured, were carried out in Samarinda, East Kalimantan province and showed that the General area of Samarinda utilized lime parasite plant as an anticancer drug against breast cancer and cervical cancer.

In principle the extract and active fraction of lime parasite is believed to have potential as herbal anticancer agent. The results on the research of Elsyana, Bintang, and Priosoeryanto (2016), $n$-hexane fraction, exhibited cytotoxic activity and also possessed antiproliferative activity on K562 and MCM-B2 cancer cell lines. Therefore, it was suggested that clove mistletoe ( $D$. petandra (L.) Miq.) had a potent natural anticancer activity. Some other studies support this statement though more researches must be performed concerning with the effects of the extract and $n$-hexane fraction of lime parasite (D. petandra (L.) Miq.) as antiproliferative cells inducing apoptosis of breast cancer of T47D line but there has been no research found up till now.

\section{EXPERIMENTAL SECTION}

Tools and Materials

A tool for extraction and fractionation are aluminum foil, paper filter, autoclave, bottle jam, bottle vial, separating funnel, Erlenmeyer flask, beaker, flask split, blander, blow dryer, Rotary evaporator, analytical scales. Tools for cytotoxic, antiproliferative, and apoptosis test are $5 \% \mathrm{CO}_{2}$ incubator with the temperature of $37{ }^{\circ} \mathrm{C}$, micropipette, blue tip, yellow tip, analytic scales, conical, microtube, hemocytometer, counter, microscope, inverted vortex, LAF (Laminar air flow), ELISA reader, flow cytometry, and camera.

The chemical used for the extraction is ethanol $96 \%$, ethyl acetate, $n$-hexane. Whereas for testing cytotoxicity, antiproliferative, and apoptosis, it is needed dimethyl sulfoxide (DMSO), $10 \% \mathrm{H}_{2} \mathrm{SO}_{4}$, Saline Buffer $1 \mathrm{x}$ Phosphate, Media culture (MK) (RPMI), MTT. $5 \mathrm{mg} / \mathrm{mL}$ PBS (50 mg $10 \mathrm{~mL}$ PBS and MTT), SDS $10 \%$ in $0.1 \mathrm{~N}$ $\mathrm{HCl}$, Foetal Bovine Serum (FBS), diphenyl tetrazolium 
bromide, sodium dodecyl sulfate (SDS), $\mathrm{HCl}, \mathrm{NaOH}$, sodium bicarbonate, (N-2, N-acetyl hydro piperaziln3ethanol sulfanic acid (Hepus), distillate, aqua function 1\% penicillin-streptomycin, $3 \%$ acridine, Orange-ethidium bromide.

\section{Research Procedures \\ Fractionation}

Fractionation was done by the method of the FCC (Fractionation liquid-Liquid) with solvent $n$-hexane, ethyl acetate, and ethanol. The extract was dissolved into 200 $\mathrm{mL}$ of ethanol and aquades with the comparison of $1: 1$ and put into a separating funnel, after that $200 \mathrm{~mL}$ of $n$ hexane was added and shuffled slowly and kept until a separate solution layer was visible. The fraction solution was then kept and separated into jam bottles and the process was repeated in the same way several times until the solution color turned clear.

Fractionation was continued using ethyl acetate with the same volume and way to get the fraction of $n$-hexane. The fraction of $n$-hexane was evaporated with a Rotary evaporator until it was thick and continued with the drying process using hairdryer (Salni, Marisa, and Mukti. 2011). The Fractionation of $n$-hexane yielded was then brought to the anticancer assay activity.

\section{Harvesting Cells and Calculation of Cells}

Take the cell from the incubator of $\mathrm{CO}_{2}$, observe the condition of cells. Harvesting Cells was done after the cells reached $80 \%$ confluence. The next step is discarding media using a micropipette, because PBS on media culture can turn trypsin non-active. Washing the cell is repeated twice with PBS volume $\pm 5 \mathrm{~mL}$. Add trypsinEDTA (the $0.25 \%$ trypsin $0.25 \%$ ) evenly and incubate in the incubator for 3 minutes. Add media $\pm 500 \mu \mathrm{L}$ to enable trypsin. Observe the state of the cell in the microscope. Apply resuspension if there is still a cell clot. Transfer cells that have broken off into the new sterile conical tube. With a counter count the cells on the hemocytometer, observe under a microscope. Calculation of the cells is done with the following formula: the number of calculated cells $/ \mathrm{ml}=\left(\sum\right.$ cell room $\mathrm{A}+\sum$ cell room $\mathrm{B}+\sum$ cell room $\mathrm{C}+\sum$ cell rooms $\left.\mathrm{D} / 4\right) \times 10^{4}$.

\section{Cytotoxic Test by the Method MTT}

T47D cell culture derived from a collection of Laboratory Parasitology Faculty of Medicine University of Gajah Mada, Yogyakarta. The cells were routinely grown with RPMI-1640 medium supplemented with 10\% fetal calf serum and $1 \%$ of penicillin/Streptomycin and incubated at humidity of $37{ }^{\circ} \mathrm{C}, 5 \% \mathrm{CO}_{2}$ in $\mathrm{T} 75(75 \mathrm{~cm} 2)$ pumpkin tubes. The potential effects on the viability of the cells are investigated using the MTT assay as the indicator of active cells on metabolic basis. Cells were diluted in medium culture into a concentration of $1 \times 10^{5}$ cells $/ \mathrm{mL}$ and squeezed into 96 holes of wells, and incubated at $37{ }^{\circ} \mathrm{C}$ with humidity of $5 \%$ of $\mathrm{CO}_{2}$ for 24 hours.

The cells were then given treatment with the extract of ethanol the active fraction of Lime parasite ( $D$. pentandra) $(1000 ; 500 ; 250 ; 125 ; 67.5 \mu \mathrm{g} / \mathrm{mL})$ via double dilution series As the positive cell controls treatment with doxorubicin was given with terraced concentration
$(0.125 ; 0.25 ; 0.5 ; 0.0625 ; 0.03125 \mu \mathrm{g} / \mathrm{mL})$. The cells were also treated with culture media (1\% of DMSO) used as negative control. After 24 hours of extracts, active fraction and drugs exposure and culture medium were removed and $10 \mu \mathrm{l}$ of MTT reactant is added. After the incubation process for 4 hours, MTT/media was removed and DMSO $(100 \mu \mathrm{L})$ was added to dissolve crystals of formazan with SDS of $10 \%$. Absorbance was measured by the ELISA reader.

The entire experiment was carried out in triplicate. The concentration of substance required for $50 \%$ of growth inhibition $\left(\mathrm{IC}_{50}\right)$ is estimated as that gives a $50 \%$ decrease of absorbance in comparison with control absorbance compared with the control incubated simultaneously without substance (Mutalib, Ali, Othman, Ramasamy, and Ramat, 2016; Yee, Fauzi, Najihah, Daud, and Sulain, 2017).

\section{Antiproliferative Test with the Technique of Doubling Time}

Doubling time is the time taken for the cancer cells to grow twice as large. The cells were starved for $24 \mathrm{~h}$ in culture media containing $0.5 \%$ FBS. Next, the cells were grown in 96 multiple dishes, at the same time samples were given with the concentrations that are not deadly (scores of $\mathrm{IC}_{50}, 1 / 2 \mathrm{IC}_{50}, 1 / 4 \mathrm{IC}_{50}$, and 1/8 $\mathrm{IC}_{50}$ ) Sampling was observed at 0,24 , and 48 hours. The amount of the living cells in each well was calculated with the MTT method and made a curve absorbance was made versus the length of incubation (CCRC, 2014).

\section{Apoptosis Assay}

The number of cells required for apoptosis assay is $5 \times 10^{5}-1 \times 10^{6}$ cells which were then planted in a microplate of 6 wells, and incubated for 24 hours. The next day the cells were given a solution of the test and then incubated again for 24 hours. The media from each well was then taken in each concentration and then put in a $15 \mathrm{~mL}$ conical tube and then washed with PBS once and then accommodated on the same conical tube. Trypsin of 250 $\mu \mathrm{L}$ was added on the wells then incubated for 3 minutes at the temperature of $37{ }^{\circ} \mathrm{C}$ (under the microscope make sure the cells were not lumpy to get maximum results). After that $1 \mathrm{~mL}$ of culture media is added and then the media was accommodated in $15 \mathrm{~mL}$ conical tubes. Centrifuged at the speed of $2000 \mathrm{rpm}$ for 5 minutes then the supernatant was removed. After added $1 \mathrm{~mL}$ of PBS media then the media moved into $1.5 \mathrm{~mL}$ conical tube and centrifuged again with a speed of $2000 \mathrm{rpm}$ for 3 minutes, then supernatant is thrown. Next annexin was added and measured with flow cytometer (Hostanska, Nisslein, Freudenstein, Reichling, and Saller, 2004; Hasibuan, and Chrestella 2015).

\section{RESULTS AND DISCUSSION}

\section{Fractionation of The Extract of Lime parasite}

24.68 grams of lime parasite extract as the results of extraction, furthermore 20.75 grams of condensed extract of lime parasite $(D$. pentandra $(\mathrm{L}$.) Miq) used for liquid solvent fractionation method (FCC). The fraction of 20.75 grams of the extract of lime parasite on fraction of $n$-hexane has a larger weight of 3.1 grams (14.93\%). 
The percentage yield of the fraction of the extract of lime parasite was $14.93 \%$ for fraction of $n$-hexane. Percentage yield results in this study differ from the results on the research of Elsyana, et al. (2016), with the percentage of yield in the fraction of $n$-hexane of $0.44 \%$, the fraction of ethyl acetate $2.45 \%$ and fraction of ethanol of $4.65 \%$ of clove parasite (D. pentandra), where the percentage of $n$-hexane fraction obtained was less than this research. The differences of results obtained may be due to different host types and methods used in fractionation.

\section{Test of Cytotoxic for $\boldsymbol{n}$-Fraction of Lime parasite}

Cytotoxic test of the extracts and fractions of lime parasite against cells of T47D cancer was done with MTT method Assay. Variation of test concentration namely $1000 ; 500 ; 250 ; 125 ; 67.5 \mu \mathrm{g} / \mathrm{ml}$. For positive control doxorubicin was used in concentrations of 0.5 ; $0.25 ; 0.125 ; 0.0625 ; 0.03125 \mu \mathrm{g} / \mathrm{mL}$, whereas the negative control used media and control cell. The density of T47D cells used in the microplate was $1 \times 10^{4}$ cells/well.

Based on the percentage of viability using excel calculation the score of $\mathrm{IC}_{50}$ for each treatment group can be determined. For $\mathrm{IC}_{50}$ the fraction of $n$-hexane is $158.280 \mu \mathrm{g} / \mathrm{mL}$. It shows that the fraction of $n$-hexane has fairly active activities that T47D cell is able to inhibit $50 \%$ on the concentration. So it can be stated that the fraction of $n$-hexane is toxic against T47D cells. It can be believed that the toxic active compound in T47D cells are present in the fraction of $n$-hexane.

Cytotoxic activity fraction of $n$-hexane of lime parasite indicates a toxicity towards T47D cells because the score of $\mathrm{IC}_{50}$ is less than $500 \mu \mathrm{g} / \mathrm{mL}$. The IC score of the sample belongs to the cytotoxic group are based on the research of Weerapreeyakul, Nonpunya, Barusrux, and Thitimetharoch, (2012) they stated that the $\mathrm{IC}_{50}$ has very powerful cytotoxicity if it is $<10 \mu \mathrm{g} / \mathrm{mL}$, the powerful cytoxicity is present if $\mathrm{IC}_{50}$ is between 10 to $100 \mu \mathrm{g} / \mathrm{mL}$, the $\mathrm{IC}_{50}$ score is cytotoxic if among 100-500 $\mu \mathrm{g} / \mathrm{mL}$.

\section{Double Time Antiproliferative Test}

Antiproliferative test is used towards fraction of $n$ hexane with 4 concentration namely $1 \mathrm{IC}_{50}, 1 / 2 \mathrm{IC}_{50}, 1 / 4$ $\mathrm{IC}_{50}$, and $1 / 8 \mathrm{IC}_{50}$. Antiproliferative test is carried out using MTT method. Data obtained is in the absorbance of living cells. Antiproliferative test proves that the number of living cells at $0,24,48$ hours which can be described in a linear regression equation is then made between the log of the number of living cells by the duration of incubation to obtain the optimum time of cells in proliferative conduct after being given the treatment.

The calculation result of the duration of doubling time (Table 2.) reveals that the inhibitory property of the test substance against the velocity of cell to conduct proliferation by comparing the duration of the doubling time of cell control with the duration of doubling time of the fraction of $n$-hexane. The fraction of $n$-hexane of lime parasite has a doubling time of IC $50 \pm 28$ hours (Table 2.), which means at the hour of 28 the cells will divide themselves into two. For $1 / 2 \mathrm{IC}_{50}, 1 / 4$ IC50, and $1 / 8$ $\mathrm{IC}_{50}$ the length of time needed for the cells to multiply themselves is in 30 hours, 31 hours and 30 hours. The cell control has a doubling time approximately 28 hours. The doubling time of the fraction of n-hexane does not differ too much when compared with cell control. However, the faction still provides inhibition in the proliferation of T47D cells.

Table 1. Results of cytotoxic test of $n$-hexane fraction of lime parasite

\begin{tabular}{lcccc}
\hline \multicolumn{1}{c}{ Material } & & Absorbance \pm SD & $\begin{array}{c}\text { \% (life } \\
\text { cell) }\end{array}$ & IC $_{\mathbf{5 0}}(\boldsymbol{\mu g} / \mathbf{m L})$ \\
\hline & 1000 & $0.155 \pm 0.0097$ & 7.241 & \\
$\begin{array}{l}n \text {-hexane } \\
\text { fraction }(\boldsymbol{\mu g} / \mathbf{m L})\end{array}$ & 500 & $0.125 \pm 0.0062$ & 3.699 & \\
& 250 & $0.224 \pm 0.0073$ & 15.348 & 158.280 \\
& 125 & $0.698 \pm 0.0017$ & 71.271 & \\
Doxorubicin & 62.5 & $0.783 \pm 0.0278$ & 81.307 & \\
$(\boldsymbol{\mu g} / \mathbf{m L})$ & 0.5 & $0.116 \pm 0.00094$ & 2.558 & \\
& 0.25 & $0.114 \pm 0.0054$ & 2.322 & \\
& 0.125 & $0.237 \pm 0.0095$ & 16.844 & \\
& 0.0625 & $0.639 \pm 0.0137$ & 64.384 & \\
\hline
\end{tabular}

Table 2. Doubling Time of the test of antiproliferation of $n$-hexane fraction of lime parasite

\begin{tabular}{lccccc}
\hline \multirow{2}{*}{ Material } & \multirow{2}{*}{ Control } & \multicolumn{4}{c}{ N-hexane fraction } \\
\cline { 3 - 5 } & & IC $_{\mathbf{5 0}}$ & $\mathbf{1 / 2} \mathbf{I C}_{\mathbf{5 0}}$ & $\mathbf{1 / 4} \mathbf{I C}_{\mathbf{5 0}}$ & $\mathbf{1 / 8} \mathbf{I C}_{\mathbf{5 0}}$ \\
\hline $\begin{array}{l}\text { Doubled cell } \\
\text { Log number of cells }\end{array}$ & 10000 & 7.240 & 8.380 & 9.000 & 9.180 \\
$\begin{array}{l}\text { Doubling time } \\
\text { (hour) }\end{array}$ & 4 & 3.860 & 3.923 & 3.954 & 3.962 \\
\hline
\end{tabular}


The results of the doubling time show that the concentration of $1 / 4 \mathrm{IC}_{50}$ is the optimum concentration of in inhibiting the growth of T47D cells when compared with other concentrations (Table 2.). If the duration of doubling time of the Concentration of $1-1 / 4 \quad \mathrm{IC}_{50}$ is described in a curve, it will form an upside down $U$ curve. According to Calabrese (2008), in the science of Toxicology, hormesis is a phenomenon of dose reaction that small doses may cause stimulation effect while large doses can cause inhibition effect, which is described as a form of the response of an upside down $U$ curve or inverted form of $\mathrm{J}$.

\section{Result of Apoptosis Induction Using Flowcytometry}

The principle of flowcytometry is using reagent of Annexin $\mathrm{V}$ to bind phosphatidylserine on the surface of cells that undergo apoptosis and Propidium iodide (PI) is used to distinguish the living cells, apoptosis, and necrosis. The percentage is calculated based on the score of apoptosis of $1 \mathrm{IC}_{50}$ and $1 / 2 \mathrm{IC}_{50}$ of fraction $n$-hexane is $158,28 \mu \mathrm{g} / \mathrm{mL}$ and $79.57 \mu \mathrm{g} / \mathrm{mL}$, with the negative control used is the control of the cell control T47D of whereas the positive control is that doxorubicin of the concentration of $0,1 \mu \mathrm{g} / \mathrm{mL}$ (Fig. 1).

Based on Table 3, It is noted that no occurrence of the increase of the percentage of the apoptosis of T47D cell after providing $1 \mathrm{IC}_{50}$ and $1 / 2 \mathrm{IC}_{50}$ of fraction of $n$ hexane when compared with the cell control . But after giving the fraction of $n$-hexane, the cells undergo necrosis with the percentage $98.83 \%$ and $97.1 \%$. So it can be deduced that the active fraction of $n$-hexane of lime parasite cannot induce apoptosis in cancer cells of T47D cancer.

Table 3. Observation the results of flowcytometry of lime parasite against T47D Cells in inducing apoptosis

\begin{tabular}{lcccccc}
\hline \multicolumn{1}{c}{$\begin{array}{c}\text { Concentration } \\
(\boldsymbol{\mu g} / \mathbf{m L})\end{array}$} & $\begin{array}{c}\text { Living } \\
\mathbf{c e l l s} \\
\mathbf{( \% )}\end{array}$ & $\begin{array}{c}\text { Early } \\
\text { Apoptosis } \\
(\mathbf{\%})\end{array}$ & $\begin{array}{c}\text { Late } \\
\text { Apoptosis } \\
(\%)\end{array}$ & $\begin{array}{c}\text { Total } \\
\text { apoptosis } \\
(\%)\end{array}$ & $\begin{array}{c}\text { Necrosis } \\
(\mathbf{\%})\end{array}$ \\
\hline Control Cell & & 96.4 & 0.47 & 1.13 & 1.6 & 2 \\
$\mathrm{IC}_{50}$ & 158.28 & 0.7 & 0.03 & 0.46 & 0.49 & 98.83 \\
$1 / 2 \mathrm{IC}_{50}$ & 79.14 & 1.81 & 0.15 & 1 & 1.15 & 97.1 \\
\hline
\end{tabular}

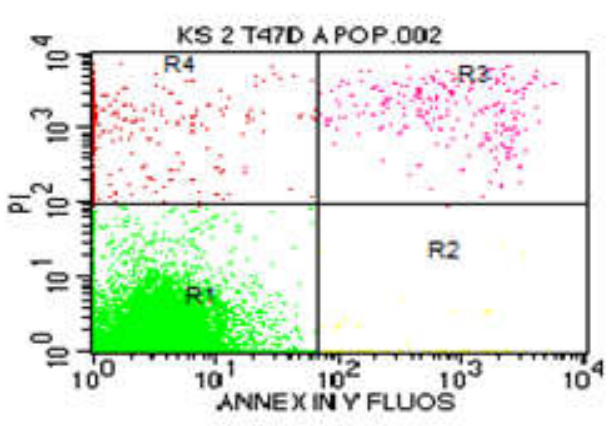

(a)

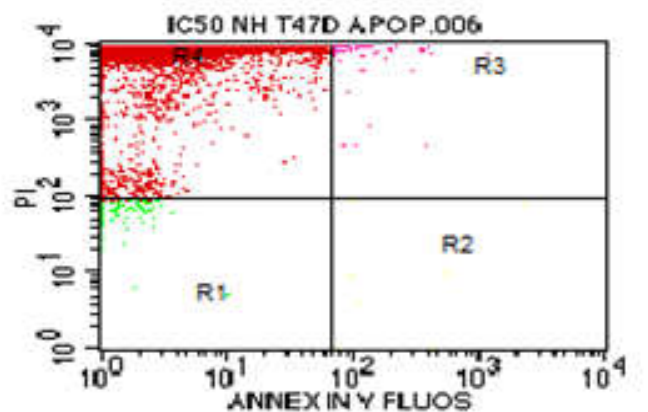

(b)

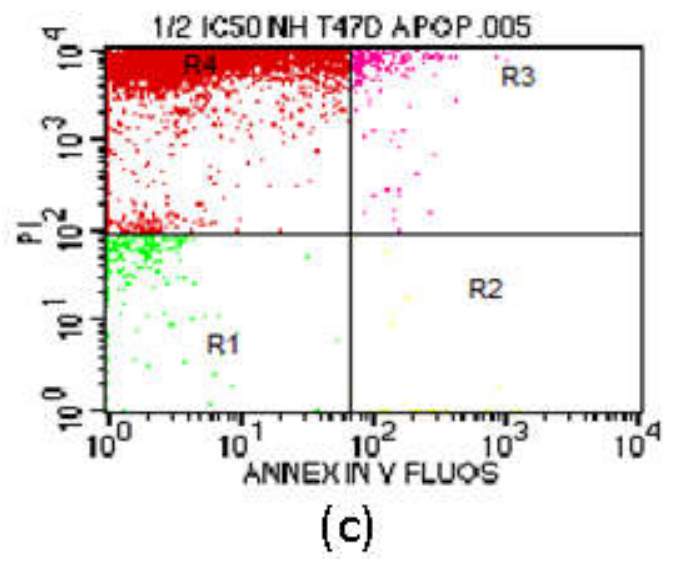

Figure 1. Result of apoptosis induction using flowcytometry. (a) Control cells, (b) cells was given treatment $1 \mathrm{IC}_{50}$, (c) cells was given treatment $1 \frac{1}{2} \mathrm{IC}_{50}$. Note: $\mathrm{R} 1=$ live cells, $\mathrm{R} 2=$ early apoptosis, $\mathrm{R} 3=$ late apoptosis and $\mathrm{R} 4=$ necrosis. 


\section{CONCLUSIONS}

Lime parasite have toxic properties against cells of T47D witch the score is $158.28 \mu \mathrm{g} / \mathrm{mL}$ as $\mathrm{IC}_{50}$ value. $n$ hexane fraction of Lime parasite with doubling time method affect the proliferation of T47D cells in 31 hour with $39.57 \mu \mathrm{g} / \mathrm{mL} \mathrm{IC}_{50}$ concentration and has no effect to induce apoptosis on T47D cells.

\section{ACKNOWLEDGEMENTS}

The authors say thankful to Universitas Sriwijaya which support this research by grant Sateks 2018 for financial support.

\section{REFERENCES}

Calabrese, E. J. (2008). Hormesis: Why It Is Important to Toxicology and Toxicologists. Environmental Toxicology and Chemistry. 27(7): 1451-1474.

CCRC (Cancer Chemoprevention Research Center). (2014). Prosedur Tetap Uji Pengamatan Proliferasi Sel (Doubling Time). Fakultas Farmasi Universitas Gadjah Mada. Yogyakarta.

Depkes RI. (2015). InfoDATIN Pusat Data dan Informasi Kementerian Kesehatan RI. Jakarta: Kementrian Kesehatan RI.

Elsyana, V., Bintang, M., Priosoeryanto, B. (2016). Cytotoxicity and Antiproliferative Activity Assay of Clove Mistletoe (Dendrophtoe pentandra (L.) Miq.) Leaves Extracts. Research Article. 6 pages.

Hasibuan, P. A. Z. and Chrestella, J. (2014). Efek Kokemoterapi Ekstrak n-Heksan dan Etilasetat Daun BangunBangun (Plectranthus amboinicus, (Lour.) Spreng.) Terhadap Doksorubisin pada Sel Kanker Payudara MCF7 dan T47D. Report research Universitas Sumatera Utara.
Hostanska, K., Nisslein, T., Freudenstein, J., Reichling, J., and Saller, R. (2004). Evaluation of Cell Death Caused by Triterpene Glycosides and Phenolic Substances from Cimifuga racemosa Extract in Human MCF-7 Breast Cancer Cells. Biol. Pharm. Bull. 27(12): 1970-1975.

Mutalib, M., A., Ali, F., Othman, F., Ramasamy, R., Ramat, A. (2016). Phenolics profile and antiproliferative activity of Cyphomandra betacea Fruit in Breast and Liver Cancer Cells. SpringerPlus. 5:2105.

Salni, Hanifa M., Ratna W. (2011). Isolasi Senyawa Antibakteri dari Daun Jengkol (Pithecolobium lobatum Benth) dan Penentuan Nilai KHM-nya. Jurnal Penelitian Sains. 14 (1(D)) 14109.

Torre L.A, Bray F, Siegel, R.L, Ferlay, J., Tieulent, J.L., and Jemal, A. (2015). Global cancer statistics, 2012. CA: a Cancer Journal for Clinicians. 65(2):87-108.

Weerapreeyakul, N., Nonpunya, A., Barusrux, S., Thitimetharoch, T. (2012). Evaluation of The Anticancer Potential Of Six Herbs Against A Hepatoma Cell Line. Chinese Medicine. 7(15): 17.

WHO. (2018). Breast Cancer. https://www.who.int/cancer/prevention/diagnosisscreening/breast-cancer/en/. (Accessed on December 2018).

Yee, S. L., Fauzi, N. F. M., Najihah, N. N. Daud, N., M., Sulain, M. D. (2017). Study of Dendrophtoe pentandra Ethyl Acetate Extract as Portential Anticancer Candidate on Safety and Toxicity Aspects. Journal of Analytical \& Pharmaceutical Research. 6(1): 00167. 